\title{
The Influence Style of Leadership Head of Subdistrict to Public Servant Apparatus Ethic in Population Field
}

\author{
Dewi Kurniasih \\ Departement of Social and Political Science \\ Indonesia Computer University \\ Bandung City, Indonesia \\ dewi.kurniasih@email.unikom.ac.id
}

\author{
Lala Lasmawati \\ Magister of Government Science \\ Langlabuana University \\ Bandung City, Indonesia \\ lalachub@gmail.com
}

\begin{abstract}
The research purpose was to measure the influence style of the leadership head of the sub district on the ethics of public servants apparatuss in the Margahayu sub district. This research is uses explanative method and data analysis approach used is quantitative. The stages of this study consisted of an analysis of the variables of style of the leadership head of sub district, analysis of the ethics of public servants apparatuss in population and the measurement of the influence between the two variables. The result in field research shows that style of the leadership head of the sub district is very high dominated by Instructive leadership style from a subdistrict head. The ethics of the public servant apparatus show quite high results, which is around 7,029. Statistical test shows that there is an influence style of Sub District Head leadership on the ethics of public servants apparatuss in the Margahayu sub district by $75.67 \%$ so that the hypothesis can be accepted. The strong influence style of the leadership head of the sub district on the ethics of public servant's apparatuss because the leadership style of the subdistrict head of Margahayu is good enough where the leadership style applied by the sub-district head of Margahayu is more inclined towards the leadership style of instruction. The leadership style of the instructions applied by the sub-district head in enforcing work regulations by carrying out strict supervision and giving sanctions to officials who violate the ethics of the apparatus so that they are well maintained. The impact of this research theoretically supports the development of Government Science and is practically an input from the subdistrict government.
\end{abstract}

Keywords - Leadership, Style, Ethic, Apparatus, Public Service

\section{I.INTRODUCTION}

District is part of regional as stated in Law No. 23 of 2014 about Regional Government. Sub districts play an important role in providing services to the community. As stated in [1] Permendagri No. 4 of 2010 about Guidelines for Sub District Integrated Administration Services. Sub district Integrated Administration Services as we call PATENT, is the implementation of public services in the sub-district from the application stage to the publication of documents in one place. The sub-district which was originally a bureaucratic center became a citizen center which became an integrated service center.

Government implementation in sub district needed good human resources as the implementor. Human resources was very decisive elements in the administration of government tasks. The ability of apparatus resources in sub-districts is the main factor that will determine the success or failure of an organization in achieving optimal public services.

Every apparatus of public servants must have an attitude, mentality and behavior that reflects the superiority of character and nobility. Public servants are obliged to develop themselves so they truly understand, appreciate, and apply ethics that are rooted in good morals.

The word of Ethics comes from the Greek "ethos" which means customs, habits, or willingness of the soul of decency [2]. We define ethics in a twofold manner as: The discipline of dealing with what is good and bad, and with moral duty and obligation; The principles of conduct governing an individual or a group [3]. At its core, ethics involves the discipline of decency. And the essence of ethics is interdependent thinking and questioning [4]. Ethics in the context of bureaucracy is "described as a norm guide for the bureaucratic apparatus in carrying out service duties to the community" [5].

There is a sub-district in Bandung Regency that has a large population. The area bordering the city of Bandung is an area that is quite dense with enough hustle and bustle. The most important population services in the District include the making of Family Cards (KK), Electronic Identity Cards (e-KTP), Temporary Residence Letters (SKTS) and there are recommended services including: making birth certificates, marriage certificates, land certificates business permit (HO), introduction to making SKCK and SIM.

The implementation of services by the apparatus has not been optimally implemented quickly, precisely, accurately, so that it often causes dissatisfaction among the community. Weak professionalism of service by the apparatus is caused by a lack of understanding and practice of the norms and ethics that apply to the apparatus.

The ethics of apparatus cannot be separated from the existence of leadership that is able to provide motivation. As stated by Iensufiie that the essence of leadership is giving motivation to others to work with maximum potential to achieve the goals or objectives that are applied [6].

To put into place effective ethics management strategies, there is no magic potion that can be applied to transform public organizations into organizations of integrity. Building an organization of integrity- workplaces where individuals treat each other with respect, take pride in their work, care about one another, promote 
accountability, and place the public interest over individual and organizational self-interest - requires substantial time, resources, and commitment, which is no small challenge [7].

Leaders in leading their subordinates use leadership styles that support subordinates, provide instruction and leaders who participate directly to their subordinates through two-way communication with their subordinates. Pasolong explain three leadership styles, such as: instruction Style, Consultative Style, Participatory Style and Delegative Style [8].

A government leader include head of sub district needs to know and understand good values in government. These values are derived from legislation, norms in the community and come from religion which are all part of the scope of government ethics.

The role of the subdistrict head is more important as a leader in upholding ethics for the apparatus to provide optimal service to the community. Style of leadership influences the ethics of public servants. Good ethics can create satisfaction for the community.

\section{II.METHOD}

This study uses a quantitative approach with explanatory survey methods. Eksplanatory Survey is a study that intends to explain the position of the variables studied and the relationship between one variable and other variables [9].

This study took place in the Margahayu sub-district. Population and samples in this study were 100 people plus 32 apparatuses. Data collection techniques through observation, questionnaires and literature study. To determine the score on the questionnaire in this study, researchers used a pattern in which respondents were asked to describe how far, each statement showed the characteristics or characteristics of variable $\mathrm{X}$ (leadership style) and variable $\mathrm{Y}$ (ethics of public service apparatus). The answers for each item are scaled according to the continuum series which consists of five points by giving a certain score.

TABLE I. Answer Category and How to Submit Questionnaire Scores

\begin{tabular}{|l|c|}
\hline Answer Category & Questionnaire Scores \\
\hline Very Aggre & 5 \\
Agree & 4 \\
Doubtful & 3 \\
Not agree & 2 \\
Disagree & 1 \\
\hline
\end{tabular}

Based on the table above, giving a questionnaire depends on the respondent's answer category. The highest score is 5 with the strongly agree category while the smallest score is 1 with the score category disagree.

\section{III.RESULTS}

Margahayu Sub District is one of the areas in Bandung Regency which has various activities such as housing, agriculture, industry and so on. Margahayu SubDistrict is seen from its location as a strategic area. This is because the location is directly bordered to Bandung City and the northern part is on the regional road lane as a liaison for the movement towards Bandung City and Bandung Regency.

Margahayu Sub District include 4 villages and 1 urban community which is Margahayu Tengah villages, Margahayu Selatan villages, Sayati villages, Sukamenak villages dan Sulaeman urban community.

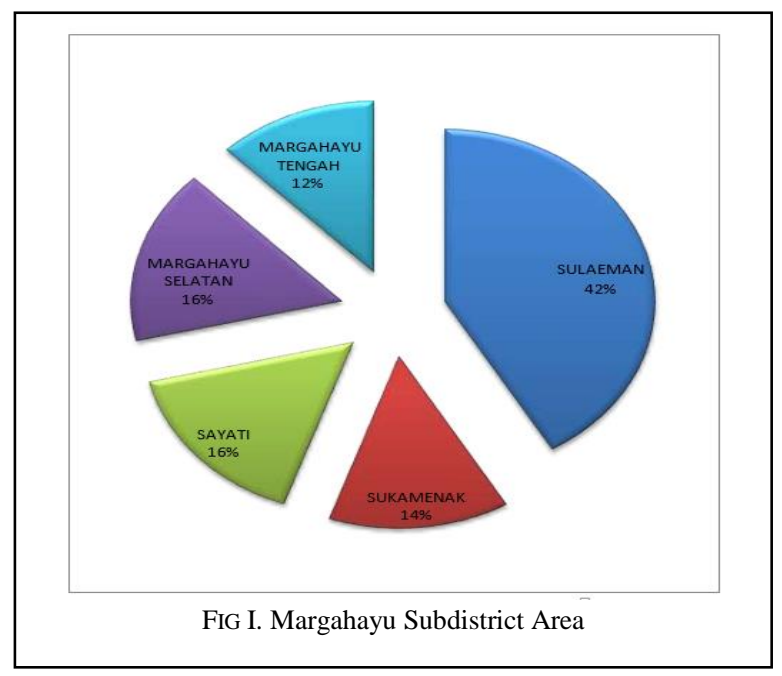

Based on the figure I above, the largest village area is Sulaeman Village at $42 \%$ and the smallest is Margahayu Tengah Village.

The population of Margahayu Subdistrict reached 130,747 people with details: Male population totaled 65,737 people and women totaled 65,010 people. This can be seen in the table below:

TABLE II

Margahayu Subdistrict Population Based on Gender

\begin{tabular}{|l|l|c|c|c|}
\hline \multirow{2}{*}{ No } & \multirow{2}{*}{ Villages } & \multicolumn{2}{|c|}{ Population } & \multirow{2}{*}{ Total } \\
\cline { 3 - 4 } & & Male & Women & \\
\hline 1 & Sulaeman & 2.795 & 2.452 & 5.247 \\
\hline 2 & Sukamenak & 15.378 & 15.010 & 30,388 \\
\hline 3 & Sayati & 18.728 & 18.546 & 37,273 \\
\hline 4 & $\begin{array}{l}\text { Margahayu } \\
\text { Selatan }\end{array}$ & 18.329 & 18.561 & 36,890 \\
\hline 5 & $\begin{array}{l}\text { Margahayu } \\
\text { Tengah }\end{array}$ & 10.508 & 10.441 & 20,949 \\
\hline \multicolumn{2}{|l|}{ Total } & $\mathbf{6 5 . 7 3 7}$ & $\mathbf{6 5 . 0 1 0}$ & $\mathbf{1 3 0 . 7 4 7}$ \\
\hline
\end{tabular}

Source: BPS Bandung Regency, 2017.

The density of the population in Margahayu Subdistrict when compared to the subdistricts in Bandung Regency is the subdistrict area with the most population. This needs to be the main concern of policy makers in Bandung Regency. 


\section{III.DISCUSSION}

\section{Data Description Variable X Leadership Style}

Variables research analysis of the variables leadership style carried out by the Head subdistrict of Margahayu (X) and Apparatus Ethics in Margahayu Sub District (Y) was based and several indicators were measured. As for the analysis of respondents' responses and the two variables can be described as follows:

\section{Dimension X1 Leadership Instructions from Respondents' Responses in the leadership style.}

To find out how the Dimension X1 of the leadership style, can be seen in the table 3 which presents the data obtained in the field.

Table III. Respondent Answer Tabs for Leadership Style Instructions $(\mathrm{n}=132)$

\begin{tabular}{|c|c|c|c|c|c|c|c|}
\hline \multirow{2}{*}{$\mathrm{NO}$} & \multirow{2}{*}{$\begin{array}{l}\text { STATEMENT IN } \\
\text { QUESTIONNAIRE }\end{array}$} & \multicolumn{5}{|c|}{ ANSWER (Fi) } & \multirow{2}{*}{$\begin{array}{l}\mathrm{SC} \\
\mathrm{OR} \\
\mathrm{E}\end{array}$} \\
\hline & & A & B & $\mathrm{C}$ & D & $\mathrm{E}$ & \\
\hline 1 & $\begin{array}{l}\text { Leaders explain their } \\
\text { respective roles }\end{array}$ & 28 & 89 & 32 & 16 & 0 & 624 \\
\hline 2 & $\begin{array}{l}\text { Leaders emphasizes two- } \\
\text { way communication }\end{array}$ & 3 & 47 & 81 & 34 & 0 & 514 \\
\hline 3 & Leaders makes a decision & 33 & 115 & 15 & 2 & 0 & 674 \\
\hline 4 & $\begin{array}{l}\text { Leaders tightens } \\
\text { supervision and } \\
\text { accountability }\end{array}$ & 15 & 79 & 44 & 27 & 0 & 577 \\
\hline 5 & $\begin{array}{l}\text { Leaders provide } \\
\text { additional instructions to } \\
\text { clarify }\end{array}$ & 14 & 55 & 67 & 29 & 0 & 549 \\
\hline 6 & $\begin{array}{l}\text { Leaders make something } \\
\text { simple and special }\end{array}$ & 15 & 56 & 69 & 25 & 0 & 556 \\
\hline 7 & $\begin{array}{l}\text { Leaders becomes a } \\
\text { reliable communicator }\end{array}$ & 18 & 89 & 48 & 10 & 0 & 610 \\
\hline 8 & Leaders are responsive & 2 & 25 & 94 & 44 & 0 & 480 \\
\hline 9 & $\begin{array}{l}\text { Leaders conduct } \\
\text { evaluation }\end{array}$ & 8 & 29 & 78 & 45 & 5 & 485 \\
\hline \multirow[t]{2}{*}{10} & Leaders monitors the task & 23 & 48 & 67 & 27 & 0 & 562 \\
\hline & AMOUNT & & & & & & 5631 \\
\hline
\end{tabular}

Source: Research Processing Results, 2018

Information :

$\mathrm{A}=$ Very Aggre

$\mathrm{B}=$ Aggre

$\mathrm{C}=$ Doubtful

$\mathrm{D}=$ Not agree

$\mathrm{E}=$ Disagree

Cumulative category intervals score answers consisting of ten questions regarding the dimension of instructive leadership by the sub-district head to Margahayu Sub District employees, can be seen the level of respondent's approval of Professionalism of Margahayu Sub District employees at 5631. Judging from the dimensions of leadership instruction, it turns out that the respondents' approval score on the camat leadership style on the performance of employees in population service who run the Service to the community in Margahayu Sub District is included in the highlands.

\section{Dimension X2 Leadership Consultative from Respondents' Responses in the leadership style of Sub Distric Head}

To find out how the Dimension of X2 leadership style, can be seen in the table 4 below which presents the data obtained in the field.

Table IV. Respondent Answer in the leadership style of Sub Distric Head

\begin{tabular}{|c|c|c|c|c|c|c|c|}
\hline \multirow{2}{*}{$\mathrm{NO}$} & \multirow{2}{*}{$\begin{array}{l}\text { STATEMENT IN } \\
\text { QUESTIONNAIRE }\end{array}$} & \multicolumn{5}{|c|}{ ANSWER (Fi) } & \multirow{2}{*}{$\begin{array}{c}\mathrm{SC} \\
\mathrm{OR} \\
\mathrm{E}\end{array}$} \\
\hline & & A & B & $\mathrm{C}$ & D & E & \\
\hline 11 & $\begin{array}{l}\text { Sub-district Head } \\
\text { explains opportunities } \\
\text { and gives opportunities } \\
\text { for clarification }\end{array}$ & 6 & 52 & 64 & 42 & 1 & 515 \\
\hline 12 & $\begin{array}{l}\text { Sub-district Head } \\
\text { conducts two-way } \\
\text { communication } \\
\text { (dialogue) }\end{array}$ & 21 & 61 & 67 & 11 & 5 & 577 \\
\hline 13 & $\begin{array}{l}\text { Sub-district head makes } \\
\text { a decision }\end{array}$ & 6 & 16 & 90 & 50 & 3 & 467 \\
\hline 14 & $\begin{array}{l}\text { Sub-district head explain } \\
\text { their respective roles }\end{array}$ & 8 & 33 & 71 & 50 & 3 & 488 \\
\hline 15 & $\begin{array}{l}\text { Sub-district head asks } \\
\text { the followers' level of } \\
\text { ability }\end{array}$ & 4 & 32 & 91 & 29 & 9 & 488 \\
\hline 16 & $\begin{array}{l}\text { Sub-district head gives } \\
\text { the impetus to make a } \\
\text { slight increase }\end{array}$ & 23 & 48 & 47 & 37 & 10 & 532 \\
\hline 17 & $\begin{array}{l}\text { Sub-district head Give } \\
\text { bonus }\end{array}$ & 4 & 17 & $\begin{array}{c}10 \\
5\end{array}$ & 30 & 9 & 472 \\
\hline 18 & $\begin{array}{l}\text { Sub-district head gives } \\
\text { praise }\end{array}$ & 2 & 42 & 70 & 48 & 3 & 487 \\
\hline 19 & $\begin{array}{l}\text { Sub-district head gives a } \\
\text { promotion }\end{array}$ & 17 & 61 & 52 & 34 & 1 & 554 \\
\hline \multirow[t]{2}{*}{20} & $\begin{array}{l}\text { Sub-district head shown } \\
\text { employees are adequate }\end{array}$ & 18 & 55 & 58 & 30 & 4 & 548 \\
\hline & AMOUNT & & & & & & 5128 \\
\hline
\end{tabular}

Source: Research Processing Results, 2018

From the table above, the respondent gives an approval score of 5128. For the highest score given a score of 5 and for the lowest score given a score of 1 , the category interval for cumulative answer scores consisting of six questions concerning the dimensions of consultative leadership style, can be seen that the level of respondent's approval of the leadership style Sub-District Head in carrying out his leadership to improve the performance of population services is 5128. As we seen from the X2 dimension, leadership style of Sub-District Head is included in the category enough. 
Dimension of X3 Leadership Participatory from Respondents' Responses in Leadership Style of SubDistrict Head

To find out how the Dimension X3 of the leadership style Sub-District Head, can be seen in the table 5 below which presents the data obtained in the field.

Table V. Respondent Answer Tabs for Leadership Style Partisipatory $(\mathrm{n}=132)$

\begin{tabular}{|c|c|c|c|c|c|c|c|}
\hline \multirow{2}{*}{$\begin{array}{l}\mathrm{N} \\
\mathrm{O}\end{array}$} & \multirow{2}{*}{$\begin{array}{l}\text { STATEMENT IN } \\
\text { QUESTIONNAIRE }\end{array}$} & \multicolumn{5}{|c|}{ ANSWER (Fi) } & \multirow{2}{*}{$\begin{array}{l}\mathrm{SCO} \\
\mathrm{RE}\end{array}$} \\
\hline & & A & B & $\mathrm{C}$ & $\mathrm{D}$ & $\mathrm{E}$ & \\
\hline 21 & $\begin{array}{l}\text { Sub-district head is an active } \\
\text { listener }\end{array}$ & 0 & 48 & 76 & 39 & 2 & 500 \\
\hline 22 & $\begin{array}{l}\text { Sub-district head } \\
\text { Subordinates make decisions }\end{array}$ & 2 & 49 & 87 & 24 & 3 & 518 \\
\hline 23 & $\begin{array}{l}\text { Sub-district head Two-way } \\
\text { communication and followers } \\
\text { are involved }\end{array}$ & 25 & 48 & 53 & 39 & 0 & 554 \\
\hline 24 & $\begin{array}{l}\text { Sub-district head supports } \\
\text { subordinates in taking risks }\end{array}$ & 30 & 92 & 33 & 10 & 0 & 637 \\
\hline 25 & $\begin{array}{l}\text { Sub-district head gives praise } \\
\text { for the success of subordinate } \\
\text { duties }\end{array}$ & 4 & 48 & 85 & 28 & 0 & 523 \\
\hline 26 & $\begin{array}{l}\text { Sub-district head builds } \\
\text { confidence }\end{array}$ & 4 & 28 & 70 & 57 & 6 & 462 \\
\hline 27 & $\begin{array}{l}\text { Sub-district head and } \\
\text { followers exchange ideas }\end{array}$ & 10 & 51 & 52 & 48 & 4 & 510 \\
\hline 28 & $\begin{array}{l}\text { Sub-district head provides the } \\
\text { necessary facilities }\end{array}$ & 3 & 37 & 86 & 37 & 2 & 497 \\
\hline 29 & $\begin{array}{l}\text { Sub-district head is able to } \\
\text { communicate }\end{array}$ & 16 & 44 & 45 & 53 & 7 & 504 \\
\hline 30 & $\begin{array}{l}\text { Sub-district head gives } \\
\text { direction }\end{array}$ & 2 & 16 & 71 & 67 & 9 & 430 \\
\hline & AMOUNT & & & & & & 5135 \\
\hline
\end{tabular}

Source: Research Processing Results, 2018

From the table above, the respondent gives an approval score of 5135. For the highest score given a score of 5 and for the lowest score given a score of 1 , the category interval for cumulative score answers consisting of ten questions regarding the dimensions of ease of action, can be seen the level of respondent's approval of the X3 Dimension of Participatory Leadership leadership style of 5135. This means that the X3 Dimension of Participatory leadership style in the Margahayu District has only reached the "enough" category that has been implemented in accordance with expectations.

\section{Dimension X4 Delegative Leadership from Respondents' Responses in Leadership Style Sub- District Style.}

The table 6 below presents the trend of paralleled data in the field in dimension X4: Delegative Leadership of Sub-District Head in Margahayu Subdistrict.
Table VI. Respondent Answer Tabs for Leadership Style Delegative $(n=132)$

\begin{tabular}{|c|c|c|c|c|c|c|c|}
\hline \multirow{2}{*}{$\begin{array}{l}\mathrm{N} \\
\mathrm{O}\end{array}$} & \multirow{2}{*}{$\begin{array}{l}\text { STATEMENT IN } \\
\text { QUESTIONNAIRE }\end{array}$} & \multicolumn{5}{|c|}{ ANSWER (Fi) } & \multirow{2}{*}{$\begin{array}{l}\mathrm{SCO} \\
\mathrm{RE}\end{array}$} \\
\hline & & $\mathrm{A}$ & B & $\mathrm{C}$ & $\mathrm{D}$ & $E$ & \\
\hline 31 & $\begin{array}{l}\text { Give a general description } \\
\text { of the task }\end{array}$ & 13 & 51 & 64 & 28 & 9 & 526 \\
\hline 32 & $\begin{array}{l}\text { Sub-district head } \\
\text { Subordinates make } \\
\text { decisions }\end{array}$ & 12 & 61 & 61 & 23 & 8 & 541 \\
\hline 33 & $\begin{array}{l}\text { Sub-district head Monitor } \\
\text { activities }\end{array}$ & 0 & 8 & 79 & 58 & 20 & 405 \\
\hline 34 & $\begin{array}{l}\text { Encourage the } \\
\text { achievement of goals }\end{array}$ & 10 & 43 & 57 & 44 & 11 & 492 \\
\hline 35 & $\begin{array}{l}\text { Sub-district head appoints } \\
\text { direct employees in } \\
\text { carrying out tasks and } \\
\text { solving existing problems }\end{array}$ & 6 & 76 & 52 & 25 & 6 & 546 \\
\hline 36 & $\begin{array}{l}\text { Sub-district head gives } \\
\text { authority and creation of } \\
\text { responsibilities to } \\
\text { members }\end{array}$ & 22 & 55 & 51 & 26 & 11 & 546 \\
\hline 37 & $\begin{array}{l}\text { Sub-district head delegates } \\
\text { to the employee in making } \\
\text { the implementation } \\
\text { accountability report }\end{array}$ & 23 & 88 & 37 & 12 & 5 & 607 \\
\hline 38 & $\begin{array}{l}\text { Sub-district head explain } \\
\text { job and function }\end{array}$ & 3 & 46 & 87 & 17 & 12 & 506 \\
\hline 39 & $\begin{array}{l}\text { Sub-district head delegates } \\
\text { to employees in the } \\
\text { execution of tasks and } \\
\text { functions }\end{array}$ & 4 & 71 & 73 & 11 & 6 & 551 \\
\hline 40 & $\begin{array}{l}\text { Sub-district head did not } \\
\text { hesitate to go directly to } \\
\text { help his subordinates }\end{array}$ & 12 & 44 & 65 & 32 & 12 & 507 \\
\hline & AMOUNT & & & & & & 5227 \\
\hline
\end{tabular}

Source: Research Processing Results, 2018

The communicative category interval answers scores consisting of ten questions concerning the dimensions of the sub-district delegative leadership in Margahayu SubDistrict, the level of respondent's approval of the implementation of the chief's delegative leadership style to his employees is 5227 .

As we seen from the dimensions of the delegative leadership style in Margahayu Subdistrict, it turned out that the respondents' approval score on the leadership style of the Camat in Margahayu District was in the sufficient category. This means that the delegative leadership style of Margahayu Subdistrict in the leadership style of the subdistrict head is quite well, according to the follow-up of the results of the report.

\section{Description of Variables $Y$ of Public Servant Apparatus Ethics}

To find out how the Variable Dimension Y Public Servant Apparatus Ethics in Margahayu Sub District can be seen in the table 7 below which presents the data obtained in the field.

Table VII. Respondent Answer Tabs for Public Servant Apparatus Ethics in Margahayu Sub District $(n=132)$ 


\begin{tabular}{|c|l|c|c|c|c|c|r|}
\hline \multirow{2}{*}{ NO. } & \multirow{2}{*}{ Indicators } & \multicolumn{5}{|c|}{$f i$} & \multirow{2}{*}{ sfi.xi } \\
\cline { 3 - 7 } & & $\mathrm{A}$ & $\mathrm{B}$ & $\mathrm{C}$ & $\mathrm{D}$ & $\mathrm{E}$ & \\
\hline 1 & Knowledge & 4 & 45 & 62 & 9 & 0 & 404 \\
\hline & know the tasks that must be & & & & & & \\
2 & done at work & 17 & 53 & 48 & 0 & 2 & 443 \\
\hline 3 & Inspiration in doing service & 11 & 62 & 45 & 2 & 0 & 442 \\
\hline 4 & Improving service quality & 5 & 59 & 54 & 0 & 2 & 425 \\
\hline 5 & Attitude and behavior & 23 & 66 & 31 & 0 & 0 & 472 \\
\hline 6 & Polite & 6 & 64 & 44 & 4 & 2 & 428 \\
\hline 7 & Friendly & 30 & 73 & 16 & 0 & 1 & 491 \\
\hline 8 & Mutual respect & 3 & 65 & 47 & 4 & 1 & 425 \\
\hline 9 & Mutual respect & 14 & 69 & 34 & 2 & 1 & 453 \\
\hline 10 & Dicipline & 6 & 41 & 71 & 0 & 2 & 409 \\
\hline 11 & Responsible & 7 & 56 & 55 & 0 & 2 & 426 \\
\hline 12 & Fair & 18 & 49 & 51 & 0 & 2 & 441 \\
\hline 13 & Service speed & 14 & 56 & 46 & 2 & 2 & 438 \\
\hline 14 & Skills & 0 & 55 & 60 & 1 & 4 & 406 \\
\hline 15 & Expertise & 27 & 69 & 22 & 0 & 2 & 479 \\
\hline 16 & Clarity & 14 & 67 & 33 & 4 & 2 & 447 \\
\hline & AMOUNT & & & & & & $\mathbf{7 0 2 9}$ \\
\hline
\end{tabular}

Source: Research Processing Results, 2018

From this table respondents give the approval score for the highest score given a score of 5 and for the lowest score given a score of 1 , then the cumulative category interval score answers consisting of two questions regarding thoughts / ideas in the public servant apparatus ethics, can be seen that the ethics of the apparatus in providing population services is good enough.

Organizations include the government in Margahayu Sub District need to take a hard look at the way they do on public servant, and decide what changes are required. They need to understand explicitly the issues related to ethical behavior now and in the future. Leaders need to have a vision of how ethics can create new possibilities for the future growth of the business, and must understand what steps they can take to lay the groundwork for connecting ethics and traditional strategy in every phase of the business[10].

The Influence Style Of Leadership Head Of Sub District To Public Servant Apparatuss Ethic In Population Field At Margahayu Subdistric

The influence of leadership style carried out by the Camat on the ethics of the public servant apparatus in the population field simultaneously, and as the results of the research that the researcher did, the researcher interpreted partially and simultaneously from the existing dimensions as follows the correlations that occur are all significant.

Calculate all path coefficients effect of variable $X$ partially on Y. From the results of statistical calculations performed then obtained can be seen in the figure 2:

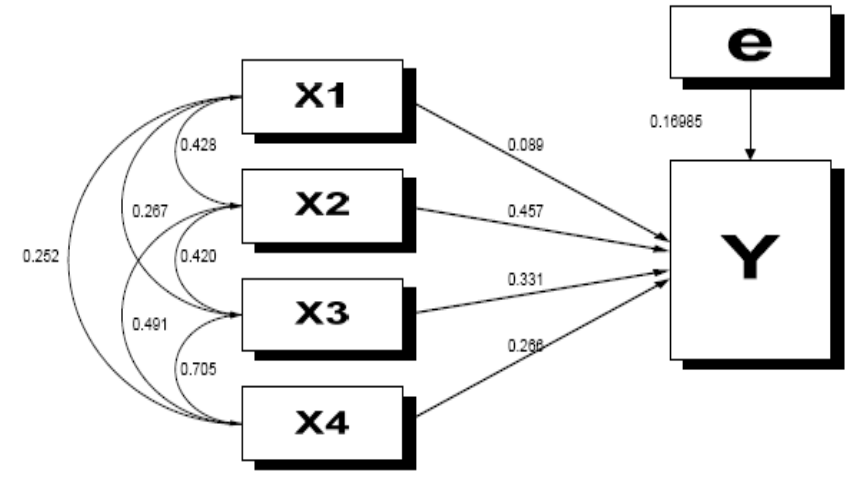

FIG II. Calculation Results of Path Structure the Leadership Style Dimension on Apparatus Ethics

Source: Research Results, 2018

Based on the results of the calculation of the Path Coefficient partially through the $\mathrm{t}$ test, the variable $\mathrm{X}$ significantly affects the variable $\mathrm{Y}$.

From the structure model of the research, it appears that all dimensions of the $\mathrm{X}$ variable are significant, meaning that the structure of the model formulated is reasonable enough to be used as a material for decision making in seeing the close relationship between Variable X (leadership style) towards Variable Y (Public Servant Apparatus Ethics).

total simultan $\times 1 \times 2 \times 3 \times 4$ only $=$

variable epsilon

$=100 \%-75.672 \%=$

$24.33 \%$

This is shown that :

A leader must have good communication skills, so that he can establish a harmonious relationship with his subordinates but in the context of work. As many as $75.67 \%$ of the leadership style influenced the performance of the population service employees while as many as $24.33 \%$ were influenced by other factors that did not participate in this study. Thus it is clear that employee performance is influenced by the communication ability of a leader especially in building teamwork as a whole to achieve goals. Thus the hypothesis proposed by the researcher is proven and tested for truth.

Basically, every government apparatus is required to have professionalism in accordance with their duties and positions. Carry out every field of work in accordance with the duties and functions structurally a credible organization becomes one of the duties and obligations of the position that must be carried out with mandate and in accordance with the values stated in the existing regulations and norms that apply in society and religion. Ethics in government carried out by the district apparatus in providing services to the community.

Government is not in the business of producing ethics, as Dennis F. Thompson reminds us (1985). It is in the business of producing public goods and services such as 
justice, transportation, air and water quality, consumer and occupational safety, national security, and protection from the misfortunes of age, poverty, or race, to name a few. Thus managers and elected office- holders are charged with providing those collective goods and services deemed desirable but often not provided by private-sector firms.

Ethics in providing services to the community is one thing that must be understood and guided by all officials and leaders. There are a series of ethical values that are placed as a reference for the apparatus in carrying out tasks including providing optimal services. Ethics itself is based on moral teachings and the formation of characters who always experience change. The community in evaluating the performance of the apparatus as a form of support for the apparatus, in accordance with the dynamics of community life itself.

The realization of all programs cannot be separated from the cooperation between the sub district head and the apparatus because in improving the performance of quality public services including in the field of population requires professional government of apparatus and good moral ethics. One of the sub-district staff explained that the relationship between the apparatus and the sub-district head went well, the sub-district head carried out his responsibilities well as what was the TUPOKSI from the sub-district head. The sub-district head always gives guidance to all of the apparatus in Margahayu Sub district to continue to provide satisfying services for the community without any distinction between the people and one another.

\section{IV.CONCLUSION}

Based on the results of the study, data analysis and discussion of the influence of leadership style on public servant ethics in the field of population in Margahayu Subdistrict, the researchers formulated the conclusion that the ethics of the apparatus in providing services in the population in Margahayu Subdistrict is influenced by the leadership style of the sub-district level. Amounting to $75.67 \%$ which is included in the strong category. The rest is $24.33 \%$ by other influences. The camat leadership style used to influence his subordinates is instructive leadership style. However, directive, participatory, and consultative leadership styles are also applied in certain matters and situations.

\section{ACKNOWLEDGEMENTS}

Head of department PostGraduate Government Science Langlangbuana University. Head of LPPM Unikom and Sub-District Head of Margahayu

\section{REFERENCES}

[1] Permendagri No. 4 of 2010 about Guidelines for District Integrated Administration Services.

[2] A.W. Widjaja. 2003. Etika Administrasi Negara. Jakarta. Bumi Aksara.

[3] Merriam-Webster's Collegiate Dictionary, 10th edition. 1993.Springfield, Mass.: Merriam-Webster, Inc.,

[4] Pastin, M. 1986.The Hard Problems of Management: Gaining the Ethics Edge. San Francisco: Jossey-Bass,

[5] Iensufiie, Tikno. 2010.Leadership untuk Profesional dan Mahasiswa. Jakarta: Erlangga.

[6] Agus Dwiyanto, etc. 2002. Reformasi Birokrasi Publik di Indonesia. Yogyakarta: Pusat Studi Kependudukan dan Kebijakan (PPSK) UGM. Journal of. Contemporary Business.

[7] Donald, C. Menzel. 2007.Ethics Management for Public Administrators Building Organizations of Integrity. New York: M.E. Sharpe. P.4-5.

[8] Harbani, Pasolong. Kepemimpinan Birokrasi.2008. Bandung : Alfabeta.

[9] Sugiyono. 2012.Metode Penelitian Kuantitatif Kualitatif \& RND. Bandung: Alfabeta. pp.21.

[10]Richard Bellingham. 2003. Ethical Leadership: Rebuilding Trust in Corporation. Massachusetts: HRD Press Inc. 